\author{
U.S. DEPARTMENT OF COMMERCE \\ National Oceanic and Atmospheric Administration \\ Environmental Research Laboratories
}

NOAA Technical Memorandum ERL ARL-30

\title{
MICROSCALE INVESTIGATION OF THE TEMPORAL CHANGES IN THE BUGGY I BASE-SURGE CLOUD
}

\section{Darryl Randerson}

This work was supported by the

United States Atomic Energy Commission, Division of Biology and Medicine, under Nevada Operations Office Contract No. SF 54-351

$$
\text { ARLV }-351-18
$$

\footnotetext{
This report was prepared as an account of work sponsored by the United States Government. Neither the United States nor the United States Atomic Energy Commission, nor any of their employees, nor any of their contractors, subcontractors, or their employees, makes any warranty, express or implied, or assumes any legal liability or responsibility for the accuracy, completeness or usefulness of any information, apparatus, product or process disclosed, or represents that its use would not infringe privately owned rights.
}

Air Resources Laboratories

Las Vegas, Nevada

March 1971 


\section{DISCLAIMER}

This report was prepared as an account of work sponsored by an agency of the United States Government. Neither the United States Government nor any agency Thereof, nor any of their employees, makes any warranty, express or implied, or assumes any legal liability or responsibility for the accuracy, completeness, or usefulness of any information, apparatus, product, or process disclosed, or represents that its use would not infringe privately owned rights. Reference herein to any specific commercial product, process, or service by trade name, trademark, manufacturer, or otherwise does not necessarily constitute or imply its endorsement, recommendation, or favoring by the United States Government or any agency thereof. The views and opinions of authors expressed herein do not necessarily state or reflect those of the United States Government or any agency thereof. 


\section{DISCLAIMER}

Portions of this document may be illegible in electronic image products. Images are produced from the best available original document. 


\section{TABLE OF CONTENTS}

-

Page

AB S T RACT

1

1. INTRODUCTION

1

2. ANALYTIC PROCEDURE

2

3. METEOROLOGICAL ANALYSIS 3

4. PHOTOGRAPHIC INTERPRETATIONS 4

$\begin{array}{lr}\text { 5. SUMMARY } & 10\end{array}$

6. ACKNOWLEDGEMENTS

7. REFERENCE 11 


\title{
MICROSCALE INVESTIGATION OF THE TEMPORAL CHANGES
}

IN THE BUGGY I BASE-SURGE CLOUD

\section{Darryl Randerson}

\begin{abstract}
A microscale analys is is presented to describe the temporal changes in the base-surge cloud generated during a Plowshare nuclear cratering event on the Nevada Test Site. The analysis shows that the inertial motion of the base-surge cloud dissipated within 1 min after detonation, so that after $\mathrm{H}+\mathrm{l}$ min, the displacement of the cloud was governed by the local air flow. The report also demonstrates how aerial photography can be used to conduct investigations of early-time cloud dynamics.

Key Words: aerial photography, base-surge cloud, meteorology, microscale analysis, nuclear debris cloud, Plowshare.
\end{abstract}

\section{INTRODUCTION}

Project Buggy 1 , the first nuclear row-excavation experiment performed in the Plowshare Program, was conducted on the Nevada Test Site at 0904 PST, 12 March 1968. Five nuclear devices, each having a yield of 1.1 kilotons, were detonated simultaneously in a dry basalt formation on chukar Mesa, $5208 \mathrm{ft}$ above MSL. The explosives were buried $135 \mathrm{ft}$ deep and were $150 \mathrm{ft}$ apart (Toman, 1969). Immediately after detonation a circular base-surge cloud was generated as well as a main cloud column; however, several minutes after detonation there was little distinction between these two clouds because they combined to form one total cloud system.

During the Buggy event, a U. S. Air Force photo-reconnaissance flight was made back-and-forth over the test area from 0900 to about 1100 PST on 12 March. Aerial photographs obtained from this reconnaissance mission provided an excellent 
be released into the atmosphere. However, the sharp temperature inversion that existed between the 8000- and 9000-ft levels would tend to act as a lid, or upper limit, for any deep mixing process. Above the 11,000-ft level the temperature lapse rate was again nearly dry adiabatic.

Figures 1 and 2 reveal the vertical and horizontal distribution of the wind just before detonation. Of particular interest is the fact that within the lowest levels of the sounding there was little directional vertical wind shear, so that the base-surge cloud was not stretched in several different directions. Figure 2 illustrates the winds detected $30 \mathrm{ft}$ above the ground near GZ, $4 \mathrm{~min}$ before and $1 \mathrm{~min}$ after detonation. Notice, in particular, that these winds were southerly at 10 to $16 \mathrm{kt}$, so that the southward movement of the base-surge cloud should have been retarded.

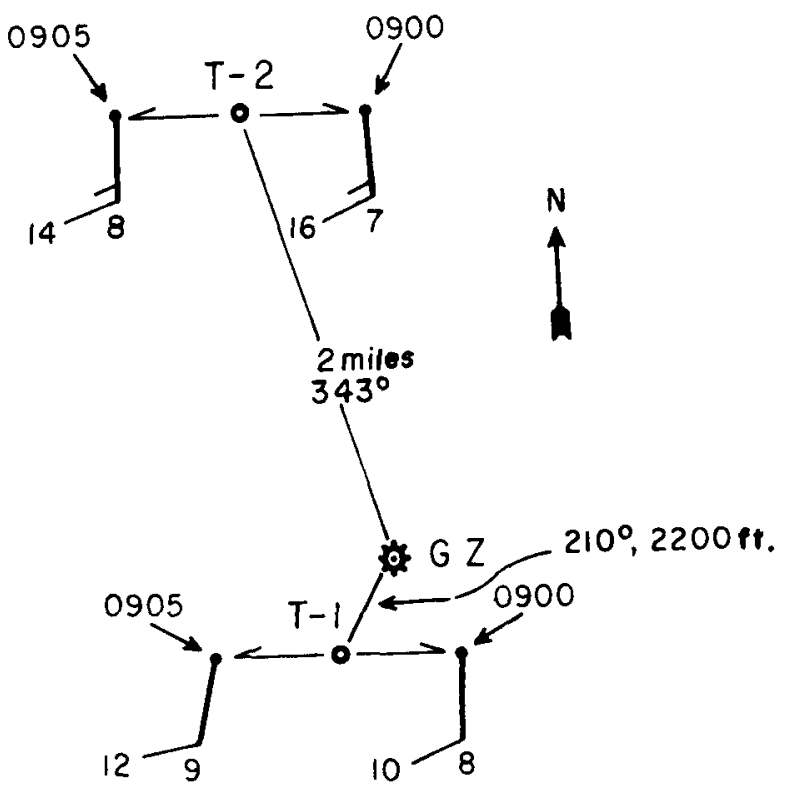

Figure 2. Wind observations from two 30-ft towers near G. $\quad$ Number left of wind barbs is wind speed in knots; number at base of barbs represents wind direction.

\section{PHOTOGRAPHIC INTERPRETA- TIONS}

All photographs of the base-surge cloud taken within 44 sec after detonation were prepared so that a rather detailed microscale analysis could be made of the growth rate of this cloud system. Because the base-surge cloud was of limited vertical extent and the pictures were taken from a nearly constant altitude of $14,700 \mathrm{ft}$ above MSL, the calculated cloud dimensions should be reliable, especially in a relative reference 
frame. Aerial photographs were also available for about 1 min after detonation; however, in the last few frames the cloud system was near the edge of each picture, and optical distortions caused by the camera lens were apparent. Consequently, these latter pictures were not considered to be of good enough quality for analysis.

Figure 3 portrays the displacement of the leading edge of the base-surge cloud for 8-sec intervals. Each contour in this figure represents a direct tracing of the base-surge cloud as it appeared in several aerial photographs taken within $44 \mathrm{sec}$ after detonation. In figure 3 , notice that the southward movement of the base-surge cloud was being retarded while the northern portion of the cloud continued moving.

This differential movement was related to the wind field and to the inertial motion of the base-surge cloud.

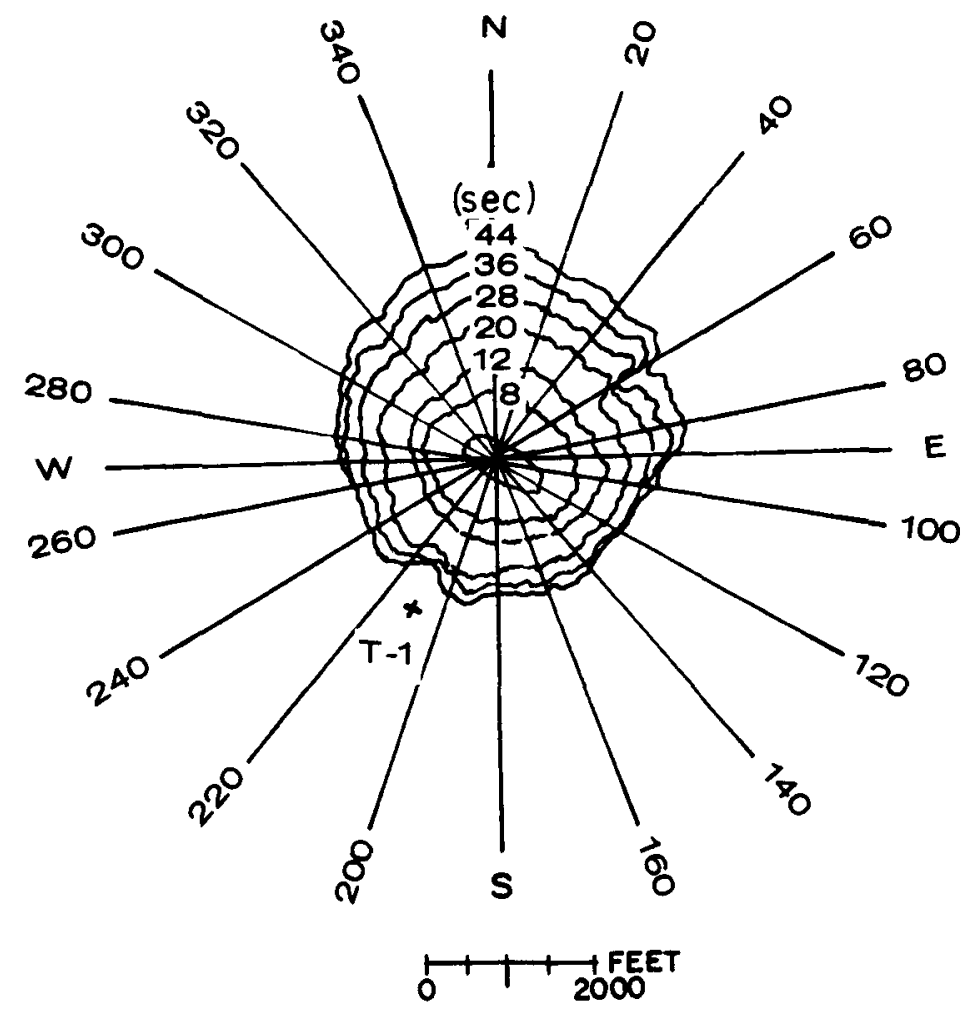

Figure 3. Positions of the leading visible edge of the basesurge cloud as determined directly from aerial photographs. 
Wind observations (figs. 1 and 2) indicate that near GZ, the surface wind was from the south $\left(180^{\circ}-190^{\circ}\right)$ at about 10 $k t$ while at the 6000-ft level the wind was southerly $\left(170^{\circ}\right)$ at approximately $14 \mathrm{kt}$. Consequently, the mean wind velocity through this shallow atmospheric layer was, in general, southerly at about $12 \mathrm{kt}$. This type air flow regime would tend to retard the southward movement of the debris cloud.

Figure 4 shows the results of the calculations of the different displacement speeds of the base-surge cloud in eight different directions from $G Z$ and the results of the calculation of each of the lines of best fit by linear regression. Displacement speeds were determined directly from the distances between cloud positions portrayed for selected times in figure 3. Although only five points were used in each case, the correlation coefficients indicate a strong linear relationship between the time and the speed of the base-surge cloud, except possibly for the NE and NW cases. Another noteworthy result is that the average slope of the regression lines has a rather small range with an average value of about $-1.69 \mathrm{ft} \mathrm{sec}-1$ ( $1 \mathrm{kt})$, representing a constant average deceleration of the leading edge of the base-surge cloud.

In figure 4 the graphs and solutions to the resulting linear equations for the $S E$, $S$, and $S W$ directions show that the inertial motion of the base-surge cloud ceased approximately $38 \mathrm{sec}$ after detonation, so that subsequent displacement of the debris cloud was governed by the wind field. The time when the entire cloud system was being driven by local winds can be obtained by assuming that the northward speed of the cloud is equal to a negative southward speed. If these two equations are solved simultaneously, one obtains a time of $46 \mathrm{sec}$. A similar solution to the $E$ and $W$ linear equations gives almost $48 \mathrm{sec}$, a close correspondence to 46 sec; the difference is explained by the fact that the 
○
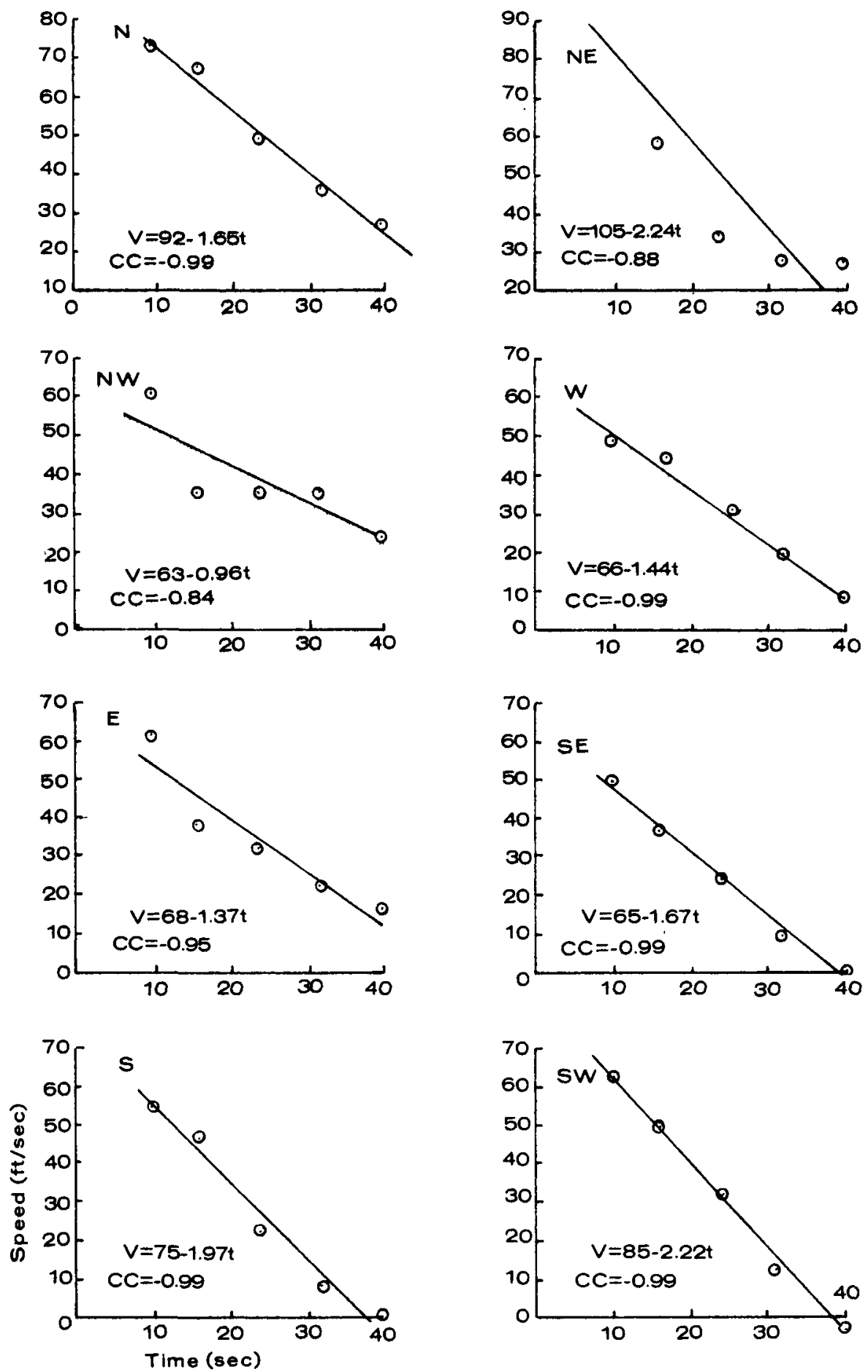

Figure 4. Temporal changes in the base-surge speed for various directions. 
four equations are only linear approximations to the observed data. These two solutions show that about 47 sec after detonation the inertial energy of the debris cloud ha\$ dissipated and that debris cloud displacement was being driven by local winds. Now, by solving the N-S and E-W sets of equations for $t=46$ and $48 \mathrm{sec}$, respectively, one finds cloud displacement speeds of 9.4 and $1.6 \mathrm{kt}$; therefore, the total cloud displacement vector is approximately $010^{\circ} @ 10 \mathrm{kt}$. This calculated displacement vector corresponds quite nicely with the wind velocities measured on a $30-f t$ tower near GZ (fig. 2). Consequently, the data in figure 4 appear to be valid, and, thereby, the linear equations derived from these data closely portray the approximate displacement speeds of the base-surge cloud from 10 sec after detonation to about 40 sec after detonation.

By planimetering around the different cloud circumferences in figure 3,1 obtained an estimate of the horizontal area of the base-surge cloud for different times. The results of these measurements are presented in figure 5 along with calculations of the horizontal area divergence of the basesurge cloud. In this figure notice that the horizontal area of the base-surge cloud grew at almost a steady, linear rate for approximately the first $44 \mathrm{sec}$ after detonation. The equation of the line of best fit through these data points is

$$
A=0.011 \mathrm{t},
$$

which represents a solution to

$$
\frac{1}{A} \frac{d A}{d t}=t^{-1}
$$

where

$$
\begin{aligned}
A= & \text { horizontal cloud area in sq. miles as viewed in an } \\
& \text { aerial photograph. } \\
t= & \text { time after detonation in seconds. }
\end{aligned}
$$




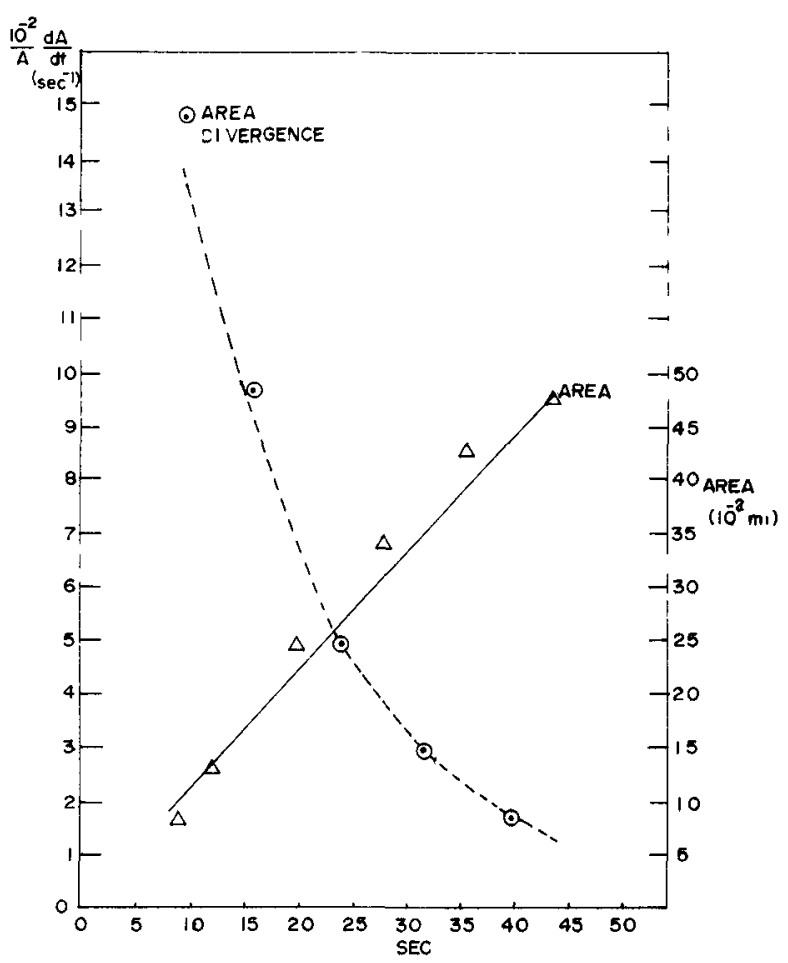

Figure 5. Temporal changes in the base-surge area $(\Delta)$ and in the area divergence (O). Solutions to (1) and (3) are included.
Although (1) is based on only six data points, it has a correlation coefficient of 0.99 . These data indicate that between 8 to $44 \mathrm{sec}$ after detonation, the base-surge cloud was apparently growing at a steady rate; however, by calculating the horizontal area divergence of this cloud system, I found that the expansion rate of the base-surge cloud was being retarded. Figure 5 reveals that this retardation was quite pronounced between 10 and $24 \mathrm{sec}$ after detonation, and that nearly all the kinetic energy of motion, generated directly and indirectly by the device, was being dissipated quite rapidly by the at-

mosphere. By fitting an exponential equation through the data points representing horizontal area divergence, I found that

$$
\nabla \cdot A \simeq 0.05 \exp [0.07(24-t)]
$$

which is another solution to (2), where $\nabla \cdot A=$ the horizontal area divergence of the base-surge cloud as determined from aerial photographs.

Equation (3) fits the five data points in figure 5 quite

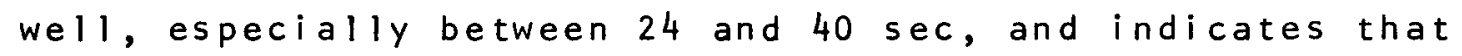
(1) does not adequately show $A$ as a function of $t$. Equation (3) and the equations in figure 4 predict that nearly all the 
base-surge cloud expansion created by internal cloud dynamics was dissipated within about 1 min after detonation. Consequently, figures 4 and 5 and (3) imply that for the Buggy event, the base-surge cloud was being influenced predominantly by atmospheric motions within 1 min after detonation.

According to Rohrer (private communication), $40 \mathrm{sec}$ after detonation the height of the base-surge cloud was approximately $125 \mathrm{~m}$ above the ground. This value was determined from special ground-based cameras. For the same time, the horizontal cloud area was estimated from figure 5 to be $0.45 \mathrm{sq}$. miles or $1.17 \mathrm{x}$ $10^{6} \mathrm{~m}^{2}$. Knowing the cloud helght and horizontal area, 1 calculated the cloud volume to be $1.46 \times 10^{8} \mathrm{~m}^{3}$, which is very close to an estimation by Rohrer (private communication) of $1.5 \times 10^{8} \mathrm{~m}^{3}$.

\section{SUMMARY}

Aerial photographs of the base-surge cloud generated by a Plowshare cratering event have been analyzed to evaluate the temporal changes that occurred in this microscale cloud system. Analyses of the base-surge pictures revealed the effects of the air flow in retarding and accelerating this cloud system and revealed a deceleration constant of about $-1.69 \mathrm{ft} \mathrm{sec}^{-1}$ for the base-surge cloud at very early times $(<1$ min after detonation). A volumetric calculation of this small cloud, based on aerial photographic data, was consistent with another value obtained from an independent analysis of photographs from ground-based cameras. Calculations of the horizontal area divergence of the debris cloud and an analysis of figure 4 indicated that within about 38 to 60 sec after detonation the motion of this cloud system was dominated by the atmospheric wind field. 
This report has demonstrated the usefulness of aerial photography in studying the small-scale behavior of a nuclear debris cloud. In future cratering events, I recommend that stereographic aerial photography be used so that a more detailed three-dimensional analysis of the debris cloud structure and dynamics can be made.

\section{ACKNOWLEDGEMENTS}

The aerial photographs were furnished by Dr. T. V. Crawford of the Lawerence Radiation Laboratory. Several constructive comments were made by Mr. Robert List of the Air Resources Radioactivity Laboratory. A special thanks to Mr. Hal Mueller of the Air Resources Laboratory for his many helpful suggestions during the preparation of the manuscript.

\section{REFERENCE}

Toman, J. (1969), Project Buggy: A nuclear row-excavation experiment, Nuclear Applications and Technology, $\underline{7}$, No. 3, pp. 243-252. 